\title{
DESIGN PRINCIPLES FOR PROFESSIONALIZING PRIMARY SCHOOL TEACHERS ON PROMOTING READING MOTIVATION
}

\author{
IRIS VANSTEELANDT*, SUZANNE E. MOL** \& HILDE VAN KEER***
}

*Department of Education and Training, Artesis Plantijn University College, Antwerpen, Belgium **Department of Learning and Behavior Problems in Education: Challenges and Solutions, Institute of Education and Child Studies, Faculty of Social and Behavioral Sciences, Leiden University, The Netherlands ***Department of Educational Studies, Ghent University, Belgium

\begin{abstract}
Studies show that teachers' continuing professional development (CPD) is essential for educational quality, and moreover, when it comes to reading, key for students' success in education and participation in our $21^{\text {st }}$ century society. Most of the research investigating professional development programs on improving teachers' self-efficacy for teaching reading and in particular on fostering students' reading motivation, however, fails to include clear and detailed descriptions of the design principles underlying the programs. Therefore, the present study provides a comprehensive description and operationalization of the design principles of a CPD program for primary school teachers focusing on promoting students' reading motivation combining Desimone's (2009) framework for effective professional development with Self-Determination Theory (Ryan \& Deci, 2000). Consequently, the CPD program's core features as distinguished by Desimone (i.e., content focus, coherence, active learning, collective participation and duration) and the need for autonomy, competence and relatedness as put central in SDT are analytically described and elaborated on. In view of reporting on the implementation check of the CPD, we further provide insight into whether these operationalized design principles were also perceived as such by the teachers participating in a first iteration of the CPD intervention.
\end{abstract}

Keywords: reading motivation promotion, continuing professional development, primary education teachers, design principles, self-determination theory

1

Vansteelandt, I., Mol, S. E. \& Van Keer, H. (2019). Design principles for professionalizing primary school teachers on promoting reading motivation. Contribution to a special issue Systematically Designed Literature Classroom Interventions: Design Principles, Development and Implementation, edited by Marloes Schrijvers, Karen Murphy, and Gert Rijlaarsdam. L1Educational Studies in Language and Literature, 19, 1-26. https://doi.org/ 10.17239/L1ESLL2019.19.04.01

Corresponding author: Iris Vansteelandt, Artesis Plantijn University College, Department of Education and Training Noorderplaats 2, 2000 Antwerpen, Belgium; and Ghent University, Department of Educational Studies, Henri Dunantlaan 2, 9000 Gent, Belgium; email: iris.vansteelandt@ap.be

(C) 2019 International Association for Research in L1 Education. 


\section{INTRODUCTION}

Research points to a decline in students' willingness to read for pleasure throughout primary and secondary education (Hornstra, van der Veen, Peetsma, \& Volman, 2013; McKenna, Conradi, Lawrence, Jang, \& Meyer, 2012; Sainsbury \& Schagen, 2004). In international comparisons, this sometimes even leads to alarming results, as is the case in Flanders (the Dutch-speaking part of Belgium) and the Netherlands, where students score below par when it comes to liking to read (Mullis, Martin, Foy, \& Drucker, 2012; Mullis, Martin, Foy, \& Hooper, 2017; OECD, 2010). These findings are cause for concern as research repeatedly points at the close relationship between affective aspects of reading (e.g., reading motivation, attitude), reading behavior and performance, and school success (De Naeghel, Van Keer, Vansteenkiste \& Rosseel, 2012; Sullivan \& Brown, 2013). Put differently, reading motivation is an important factor to promote when aiming at enhancing students to become and remain competent readers and successful students (Wigfield, Gladstone, \& Turci, 2016).

Teachers play an important role in fostering their students' motivation to keep engaging in reading activities such as reading different fictional and literary texts (Afflerbach, Cho, Kim, Crassas, \& Doyle, 2013; Applegate et al., 2014). Unfortunately, the number of (pre-service) teachers who are low in reading motivation themselves is relatively high (Nathanson, Pruslow, \& Levitt, 2008; Vansteelandt, Mol, Caelen, Landuyt, \& Mommaerts, 2017). This is especially worrisome, given the knowledge that teachers who are frequent readers themselves and who share how their reading experiences have an impact on their own lives, are most likely to show a high selfefficacy regarding teaching reading and to use recommended instructional literacy practices promoting their students' willingness to read (McKool \& Gespass, 2009; Morrison, Jacobs, \& Swinyard 1998). By doing so, these teachers stress explicitly the crucial affective aspects related to reading and can have an actual positive impact on their students' reading motivation (Afflerbach et al., 2013; De Naeghel, Van Keer, \& Vanderlinde, 2014; De Naeghel et al., 2016; Guthrie \& Klauda, 2014). More specifically, showing motivating teaching behavior in the classroom seems to depend on at least the following three elements: (1) teachers having the indispensable knowledge, i.e. they should know what reading motivation is (Conradi Jang, \& McKenna, 2013; Guthrie \& Wigfield, 2000), what it consists of (De Naeghel et al., 2012; Schiefele, Schaffner, Möller, \& Wigfield, 2012), why it is vital to explicitly focus on in the classroom and how to promote it best (McKool \& Gespass, 2009); (2) teachers disposing of the necessary skills, i.e. they should have the skills to effectively foster students' motivation in the classroom (De Naeghel et al., 2014; Guthrie \& Klauda, 2014); and moreover, (3) teachers having a positive attitude toward reading and being motivated readers themselves (both personally and professionally) and showing strong self-efficacy beliefs when it comes to promoting their students' reading motivation (e.g., Morrison et al., 1998). Taking these three elements into account, teachers are likely to offer their students the necessary high-quality reading 
education that can be expected to alter the trend that students' reading motivation will decline throughout their educational careers.

Research showed that the continuing professional development (CPD) of teachers is a requirement to ensure high quality education (Coe, Aloisi, Higgins, \& Major, 2014; McArdle \& Coutts, 2010; OECD, 2014; Postholm, 2012; Wei, DarlingHammond, Andree, Richardson, \& Orphanos, 2009). This is also the case when it comes to reading motivation promotion (De Naeghel et al., 2014, 2016; Guthrie \& Klauda, 2014; Jang, Conradi, McKenna, \& Jones, 2015). Kelchtermans (2004) defines CPD as "a learning process resulting from meaningful interaction with the context (both in time and space) and eventually leading to changes in teachers' professional practice (actions) and in their thinking about that practice" (p. 220). In addition, CPD can be considered as an ongoing process, where teachers are motivated to persist in professionalizing themselves in order to continuingly improve their competences (i.e., knowledge, skills and attitudes) and, hence, those of their students (Kennedy, 2014). In this respect, well-designed CPD programs that are based on strong theoretical and empirical research that can be implemented with fidelity are required (Avalos, 2011; Borko, 2004; Kennedy, 2016; Opfer \& Pedder, 2011; Timperley, Wilson, Barrar, \& Fung, 2007). However, such programs are not common practice yet. The aim of this study is to show how a CPD can be developed by grounding the program in an overall theory of improvement, taking into account both a theory of change (i.e., the relations between the characteristics of teacher professional development and teachers' knowledge, skills, attitudes, and practice) and a theory of instruction (i.e., the influence of changing teaching practices on students' learning and achievement) (Kennedy, 2016; Merchie, Tuytens, Devos, \& Vanderlinde, 2016; Van Veen, Zwart, \& Meirink, 2012).

Two frequently cited models for evaluating a professional development program and mapping the possible effects are the five-stages-model of Guskey $(2000,2014)$ and the so-called path model of Desimone (2009). Both models show some degree of similarity as they both integrate a theory of change and instruction, acknowledge the necessity to formulate clear design principles when developing a professional development program, and refer to teaching and student learning and context as crucial elements in every professional development program. The framework of Desimone (2009) appears particularly interesting as it explicitly highlights the interactive relationships between core features of professional development and increased teacher competence, change in instruction, and finally to improved student learning. This means, for example, that a change in teachers' competence can lead to a change in teaching behavior or reciprocally. Desimone's model (2009) appears to be leading in the literature as can be seen in the work of other researchers who applied or adapted her model (Boston, 2013; Kang, Cha, \& Ha, 2013; Labone \& Long, 2016; Merchie et al., 2016; Van Veen et al. 2012).

In Desimone's framework (2009) five evidence-based core features for effective professional development (i.e., design principles) are distinguished. First, reference is made to the content focus of a program: what teachers learn through professional development in relation to subject matter content and how students learn this 
content. A second core feature relates to active learning in the professional development: teachers learn actively through continuing and active inquiry of practice by means of for example actively observing, reviewing, reflecting, or discussing. Third, coherence is considered an essential professional development feature: teacher's learning needs to be aligned with their knowledge, beliefs, goals and with current reforms and policies. Duration is the fourth fundamental principle: an intensive program with a minimum of 20 hours of contact time and spread out over time, making follow-up possible, is recommended. Finally, collective participation turns out to be a key design principle: bringing teachers together to actively collaborate with each other. Although most models on professional development and the design principles mentioned in the models can be considered conceptual and therefore general in nature and consequently not exclusively linked to a specific educational domain (e.g., reading, mathematics), when operationalized in detail they are a strong scientific starting point for building a domain-specific professional development program, which can be implemented, evaluated, disseminated and replicated (e.g., Santagata \& Bray, 2015).

As the present study explicitly focuses on stimulating reading motivation, the need to also integrate insights from a motivation theory when designing a CPD program becomes apparent. Different motivation theories can be considered, for example the Expectancy-Value Theory (Wigfield \& Eccles, 2000), the Social Cognitive Theory (Bandura, 1986), and the Self-Determination Theory (Ryan \& Deci, 2000). In educational settings, increasing attention is being paid to the Self-Determination Theory (SDT) as the theoretical frame of reference (Lazowski \& Hulleman, 2016). A recent meta-analysis on the effects of reading motivation interventions in particular (Van Steensel, Van der Sande, Bramer, \& Arends, 2016) revealed that the majority of studies referred to SDT (Ryan \& Deci, 2000) as the theoretical basis for their intervention. Moreover, SDT is currently referred to as an interesting and most valuable innovative motivation theory, also when specially aiming at stimulating students' reading motivation (e.g., De Naeghel et al., 2012, 2016).

SDT distinguishes between autonomous motivation (i.e., engaging in activities with a sense of willingness) and controlled motivation (i.e., engaging in activities with a sense of pressure or coercion) and states that one's autonomous motivation - as opposed to controlled motivation-should be fostered and nurtured. This can be realized by stimulating the inherent psychological need for autonomy (the experience of psychological freedom), providing structure in view of fostering the need for competence (the experience of feeling confident and effective), and nurturing the need for relatedness (the experience of feeling related to others). In a CPD program, insights from SDT can be integrated in both the program's content focus (i.e., providing knowledge on autonomous and controlled motivation) as well as in the design principles. The latter is particularly important taking into account the idea of congruent teaching, stressing to teach what you preach and to be a good model of the kind of teaching you want to promote in CPD (Aelterman et al., 2013; De Naeghel et al., 2016; Swennen, Lunenberg, \& Korthagen, 2008). In this respect, using an SDT approach in CPD aims at and implies that participating teachers 
themselves (1) are being motivated throughout the program by fostering their psychological needs for competence, relatedness, and autonomy and (2) increase their knowledge, skills, and self-efficacy beliefs regarding reading motivation promotion, given the specific content focus of the CPD program.

Combining both the design principles distinguished in Desimone's (2009) framework for effective professional development with insights from SDT can be considered a strong starting point when developing a CPD program's underlying design principles. However, the question arises as to how these principles are actually operationalized (translated into practice) and implemented during a CPD program (Santagata \& Bray, 2015). This lack of detailed descriptions and operationalizations of the design principles underlying many CPD programs is often denoted in the literature, although they can be considered critical for the implementation, dissemination, and replication of programs (Santagata \& Bray, 2015; King, 2014). Therefore, at least the rationale behind each design principle as well as the facilitators' instructional and participants' learning activities should be elaborated on clearly in order to show how the CPD program is grounded in Desimone's framework and SDT. Furthermore, to gain insight into CPD programs' implementation fidelity, it is recommended to check how the program and more specifically its underlying design principles were implemented and whether they are perceived by the participants as intended by the designers (Smith, Daunic, \& Taylor, 2007; Swanson, Wanzek, Haring, Ciullo, \& McCulley, 2013). As recommended in the review study by O'Donnell (2008), the added value of such an implementation check lays also in the fact that researchers are encouraged to actively reflect beforehand on the design principles that underlie a specific CPD program, how they should be defined, operationalized, implemented and evaluated and then adjusted when necessary. More specifically, given the present study's focus, the implementation of the integration of both Desimone's design principles (20009) and design principles grounded in SDT should best be followed-up and verified by the people taking part in the CPD program. The implementation check is preferably executed using a multiactor approach, combining participants' evaluation with additional ratings of for example external observers or CPD facilitators (Dumas, Lynch, Luaghlin, Smith, \& Prinz, 2001).

\section{PRESENT STUDY}

The present study is part of a larger study on the design, implementation and evaluation of a year-long CPD program for newly qualified primary school teachers. Six professionalization sessions were planned throughout the school year and participants met for at least 24 hours with the same facilitator. In the present study, we exclusively focus on analytically presenting the description and operationalization of the CPD program's underlying design principles.

The CPD program was developed in 2016 after the publication of the results of The Teaching and Learning International Survey (TALIS; OECD, 2014). These TALIS results revealed that Flemish primary school teachers do attend professional 
development initiatives, but only with a low intensity (i.e., on average three days per year) and they mostly participate in short-term programs (e.g., half-day conferences or workshops). This may also be due to the fact that hardly any long-term CPD initiatives were available at that time. Research, however, has repeatedly shown that these short-term initiatives are less effective than longer programs and programs that are more unfolded over time (e.g., courses with a follow-up during a semester) (e.g., Yoon, Duncan, Lee, Scarloss, \& Shapley, 2007). Next to taking into account the TALIS results, the CPD responded to the call in the literature for also addressing more the affective side of reading (e.g., reading motivation) for both students and teachers than is currently done (i.e., predominant focus on the cognitive aspects of reading) in order to improve students' chances on academic and societal success (e.g., Hattie, 2009; Sullivan \& Brown, 2013).

When creating the content of the CPD program, a multiliterate view on reading was adopted. Next to focusing on books of fiction and non-fiction, also other reading materials, such as newspapers, magazines, and comics were focused on. The reading of these different materials in both print and digital formats were considered. After all, research indicates that the explicit inclusion of print and digital reading is necessary to relate to the reading of teachers and students living in the 21st century (Alexander, 2012; Leu, Kinzer, Coiro, Castek, \& Henry, 2013; Schiefele et al., 2012). As studies also showed the importance of teachers' and students' reading of literary texts in education and beyond (e.g., Klauda \& Guthrie, 2015; Merga, 2015), specific attention was paid to the inclusion of a variety of fictional and literary texts (e.g., picture books, short stories, poetry, novels).

To move the field of teachers' continuing professional development regarding reading instruction and reading motivation promotion in particular forward, the present study aims to describe-analytically and in detail-the operationalization of the design principles of a CPD program supporting primary school teachers in fostering their students' reading motivation. Moreover, in view of reporting on the implementation check of the CPD program's design principles, the present study also aims to examine whether the participants of the CPD program, an external observer, and the facilitator experienced the underlying design principles grounded in Desimone's framework and SDT as intended by the program designers.

METHOD

\section{Procedure}

A stepwise procedure was used to design the CPD program, in order to select, analyze, operationalize, and check the implementation of the design principles. This was done by a team of practitioners (i.e., five teacher educators, four members of official institutions in view of supporting schools and three members from organizations specialized in fostering reading in education) and five researchers who all had expertise in the field of reading (motivation) and/or CPD. More specifically, in all 
steps of the design process that are explained in more detail below, (a) the first author initiated the process by making proposals and asking for detailed feedback from the other team members; (b) adjustments were made based on the feedback and further analysis of the literature; and (c) this process was repeated until consensus on the design, its operationalization and implementation was reached in the team. In the first step of the program design, the relevant literature was consulted and analyzed, including reviews and meta-analyses (e.g., Avalos, 2011; Kennedy, 2016) and single theoretical and empirical studies (e.g., De Naeghel et al., 2016; Schiefele et al., 2012). More specifically, it was analyzed (1) which theories and frames of reference regarding professional development in general and on (reading) motivation in particular are often referred to and can be considered leading in the literature to ground the CPD program in; and (2) which design principles are referred to as indispensable and should be taken into account and selected when operationalizing and implementing the CPD program. In the second step and in accordance with Rijlaarsdam et al. (2018), the CPD facilitator's instructional and participants' learning activities were designed. Both were aligned with the selected design principles and developed simultaneously, as both are inherently connected. In a third step, in accordance with De Smedt, Graham, and Van Keer (2018) a brief questionnaire was developed to assess the implementation quality of the design principles underlying the developed CPD program (see section on Instruments for more details).

\section{Participants}

Eight primary school teachers ( 7 female, 1 male) participated in the year-long CPD program with six 4-hour face-to-face sessions extended over the school year. On average, participants were 23.6 years old $(S D=2.82)$. All participants were native Dutch speakers and had Dutch as their first reading language. They were all newly qualified primary school teachers in their first $(62.5 \%)$ or second year $(37.5 \%)$ after graduating from a three-year professional bachelor program for teacher education. They all subscribed to the program after receiving a flyer and some additional information on the program (see Appendix). Since one of the aims of all teacher education programs in Flanders is to educate pre-service teachers with the necessary knowledge, skills, and attitudes for becoming effective language and reading teachers (Flemish Ministry of Education and Training, 2008), attention is being paid to reading (education) in all teacher education programs, yet not beyond graduation. The participants were all working in a multilingual primary school in Antwerp (Belgium) and taught in classes ranging from Grades 2 to 6, with most of them teaching Grade 4 (37.5\%) and only 1 participant teaching Grade 6, while the others were equally distributed over the other grades. The first author of this article acted as the CPD facilitator and has 10 years of teaching experience in the field of teacher education (i.e., working as a teacher educator specifically working on topics related to reading in primary school) and in research in the field of reading and CPD. Additionally, in view of integrating a multi-actor approach in the implementation 
check, a researcher in the field of reading motivation, who also has teaching experience, acted as an external observer by observing the first four sessions.

\section{Instruments}

A brief questionnaire of seven statements was used to examine whether the design principles underlying the CPD program were perceived as intended by the researchers (i.e., grounded in Desimone's framework and in SDT). The participating teachers as well as the facilitator and external observer, independently and individually completed the questionnaire at the end of each CPD session. The questionnaire contained one statement per design principle, measuring the perceived extent to which that design principle was implemented during a particular session. The answer options ranged between $1=$ not true at all, to $5=$ completely true (see Table 1). It should be noted that the design principle duration was not measured, because this design principle was interpreted to be more related to the design of the CPD program as a whole (i.e., referring to the total number of CPD sessions) and not to every specific session. Furthermore, the external observer did not rate the design principle coherence, as she could not relate enough to the specific goals the participants had regarding their daily teaching practice.

\section{RESULTS}

\section{Design principles of the CPD program}

Table 2 presents the underlying design principles of the CPD intervention based on the literature study, and the related instructional and learning activities. 
Table 1. Implementation check questionnaire

\begin{tabular}{ll}
\hline Design principles of the CPD program & Statements related to the design principles of the CPD program \\
\hline Content focus & During this session attention was paid to fostering my students' reading motivation linked to my daily practice. \\
Active learning & This session was an active learning session where I worked, learned and reflected actively about fostering my students' reading motivation. \\
Coherence & What was discussed during this session fitted well with my beliefs and the goals I have to achieve as teacher. \\
Collective participation & During this session we worked and learned together. \\
Autonomy support & During this session enough attention was paid to sharing suggestions fitting my interests, for example a suggestion to make teaching materials together. \\
Competence support & During this session enough attention was paid to giving and receiving positive feedback. \\
Relatedness support & During this session attention was paid to the relatedness between participants. \\
\hline
\end{tabular}

Table 2. Design principles, facilitator's instructional activities, and participants' learning activities in a continuous professional development program (CPD) for participating primary school teachers aimed at fostering students' reading motivation

Design principles of the CPD program

\section{Content focus}

Providing participants with information on and skills to increase students' reading motivation.
Examples of facilitator's instructional activities in the CPD program -offers participants a variety of reading materials to foster their students reading motivation (e.g., different fictional and/or literary texts as for example picture books, poetry or novels; digital/on paper).

-points participants to different ways to find and select motivating reading materials to foster their students' reading motivation (e.g., using online catalogues suitable for their students to find a variety of text genres as for example fiction/literary texts).

-points participants to various strategies to enhance autonomous reading motivation (e.g., being able to respond to their students' reading interests). -alerts participants to different ways to create a visible motivating reading environment in collaboration with their students (e.g., teacher's an students' book suggestions are put in the spotlight in the classroom)
Examples of participants' learning activities in the CPD program

-get acquainted with a variety of reading materials presented by the facilitator and also introduce new materials themselves of which their students are motivated about.

-get acquainted with and use different ways to find and select motivating reading materials for their students.

-get acquainted with and use various strategies to enhance the autonomous reading motivation of their students.

-get acquainted with and use different ways to create a visible motivating reading environment in collaboration with their students and also introduce stimulating reading environment practices they themselves and their students are motivated about. 
2. Active learning

Participants' continuous inquiry of practice, co-creation of and reflection on professional and academic knowledge to increase students' reading motivation.

3. Coherence

Alignment of the CPD program with participants' goals, beliefs and with current educational reforms and policies to increase students' reading motivation.

\section{Duration}

Participants taking part in extended and intensive CPD program when aiming at fostering students' reading motivation, i.e. of sufficient duration with activities that are spread out in time and include at least 20 hours of contact time.

5. Collective participation Participants collaborating about each other's teaching practices to increase students' reading motivation. -stimulates participants observing/sharing their teaching practices in view of fostering students' reading motivation.

-stimulates and guides interactive feedback and discussion on participant observed/shared teaching practices in view of fostering students' reading motivation

-stimulates designing lessons, making materials, etc. together with other participants and the facilitator.

-stimulates participants reviewing and reflecting on their own and other participants' work together with other participants and the facilitator in view of fostering their students' reading motivation.

-relates closely to the participants' daily teaching practices (e.g., focusing on the actual reading motivation of their students, being able to assess and monitor this).

-stimulates participants to focus on the beliefs and goals they want to achieve regarding their students' reading motivation; knowing how closely reading motivation, reading behavior and reading competence are related to each other.

-stimulates participants to relate their teaching practices to school policy and reforms regarding students' reading motivation (e.g., the need for schools to focus on reading in a well-defined language policy plan).

-organizes 6 face-to-face sessions (4 hours/session) throughout the school year, with a specific educational focus for each session, namely (1) motivating instructional practices, (2) multilingual context, (3) differentiated instruction, (4) linguistically responsive teaching, (5) assessing reading motivation; and (6) reading policy as a corner stone in a school's language policy.

-stimulates online continuous professional development for the participants between the face-to-face sessions (e.g., through an online tool decided on by the participants).

-stimulates participants to meet in educational contexts/locations that relate strongly to the content focus (e.g., their classroom, library, readin organizations).

-stimulates participants to prepare well for every face-to-face session (e.g. when focusing on fostering students' reading motivation participants prepare questions, teaching practices (with photo/video-material) or prepare questions, teaching practices (with photo/video-material) the facilitator).

the facilitator). -stimulates participants to share and elaborate on teaching practices motivating reading materials for their students, how they use differentiated instruction to foster all their students' reading motivation, how they address the multilingual setting they are working in).

-stimulates participants' interaction (e.g., discussion, feedback) about thei own and others' teaching practices in view of fostering their students reading motivation (e.g., how they turn their classrooms into visible motivating reading environments, which literary texts work in which context, how they focus on reading motivation when teaching, for example, mathematics or biology) observe/share their own teaching practices (e.g., observing/sharing short video clips where teachers focus on enhancing their students' reading motivation and this for example by getting them acquainted with reading materials (e.g., literary texts) they can choose from, are related to their interests, etc.)

give feedback and join discussions on participants' observed/shared teaching practices in respect of enhancing students' reading motivation.

design lessons, make materials, etc. together with other participants and the facilitator.

-review and reflect on their own and other participants' teaching practices in respect of enhancing their students' reading motivation together with other participants and the facilitator.

-in view of fostering their students' reading motivation they assess their students' reading motivation, monitor it continuously, and relate their teaching practices to this knowledge.

-participants express the beliefs and goals they have and they want to achieve in view of fostering their students' reading motivation; participants discuss the close relationship between reading motivation, reading behavior, and reading competence with each other

-participants are able to relate their beliefs and goals regarding their students' reading motivation to school policy and current educational reforms.

participate actively in close co-operation with the other participants and in vew of fostering their students' reading motivation in 6 face-to-face sessions (4 hours/session) throughout the school year, with a specific educational focus for each session, namely (1) motivating instructiona practices, (2) multilingual context, (3) differentiated instruction, (4) inguistically responsive teaching, (5) assessing reading motivation; and (6) reading policy as a cornerstone in a school's language policy.

participate actively in the online continuous professional developmen between the face to-face sessions (e.g., by sharing motivating readin materials, helping each other with motivating teaching materials regarding reading motivation, pointing to motivating reading practices regarding national reading campaigns).

-propose motivating educational contexts/locations that relate strongly to the content focus and participate actively in these contexts (e $g$ by sharin hare their reading materials).

-prepare well and in advance for every face to face session.

share and elaborate on their teaching practices fostering their students reading motivation. They for example share how they choose motivating reading materials for their students or elaborate on how they use differentiated instruction to foster all their students' reading motivation. -interact (e.g., discussion, feedback) about their own and others' teaching practices in view of fostering their students' reading motivation. They for example talk about how they turn their classrooms into visible motivatin reading environments or discuss about which literary texts work best in which context and how they focus on reading motivation when teaching for example mathematics or biology. 
6. Autonomy support

Participants' need for autonomy (i.e., the experience of a sense of volition or psychological freedom).

7. Competence support

Participants' need for competence (i.e., the experience of being confident and effective in action).

8. Relatedness support

Participants' need for relatedness (i.e., th experience of feeling connected to and accepted by others). -stimulates participants' cooperation and co-creation in view of fosterin their students' reading motivation (e.g. designing lessons and materials linked to motivating instructional practices as for example regarding book talks).

-provides choices (e.g., offering participants/students a variety of literary texts that they can choose from).

-aligns with participants interests (e.g., offering participants/students variety of literary texts that fit their interest).

-considers highly the participants' perspectives and behaviors (e.g., relate highly to the participants' teaching practices in view of fostering their students' reading motivation).

-stimulates communicating about participants' expectations of the CPD e.g., expectations on where to find motivating reading materials for their students, which instructional teaching activities have which impact in view of reading motivation).

-provides participants with optimal challenges (e.g., to be able to integrate differentiated instruction regarding reading motivation to teach linguistically responsive in a multilingual setting by for example making the reading environment in the classroom visible multilingual).

-offers help and support (e.g., before and during the face-to-face sessions explicitly asks the participants if they need help and support when it comes to fostering their students' reading motivation).

-provides positive feedback (e.g., explicitly relates to all participants teaching practice when it comes to fostering their students reading motivation and positively stimulates them when for example putting a cocreated lesson in practice).

-stimulates involvement (e.g., by inviting participants to express themselves in various ways).

-creates a safe motivating learning environment, for example by bearing mind that participants like to feel connected to and accepted by others. cooperate and co-create in view of fostering their students' readin motivation (e.g designing lessons and materials linked to motivating instructional practices as for example regarding book talks).

-make choices in view of fostering their students' reading motivation (e.g. they choose from a variety of literary texts that suit their teaching practice and context best).

-make clear in their preparation before the session and also during the ctual session what they are interested in when it comes to enhancing their students' reading motivation, hereby the program fits the participants' interests (e.g., which instructional strategies in promoting their students reading motivation align best with their interests regarding their students' reading motivation).

-share their perspective and behavior in view of fostering their students reading motivation (e.g., relate highly to their daily teaching practice and their students' actual reading motivation).

-communicate their expectations of the CPD regarding enhancing their students' reading motivation (e.g., expectations on the accessibility of motivating reading materials for their students).

-take up optimal challenges (e.g., integrate differentiated instruction regarding reading motivation in their daily teaching practice, teach linguistically responsive in a multilingual setting by for example providing literary texts in different languages and making them visible in the reading environment).

-ask help and support (e.g., before and during the face-to-face session explicitly share if they need help and support when it comes to fostering their students' reading motivation).

-are responsive to positive feedback (e.g., regarding a co-created lesson well put in practice).

-are actively involved and engage and express themselves in various ways, in oral and/or written forms (e.g., during the face-to-face sessions, using the online tool, sometimes more one-to-one, often collaborating closely).

-feel part of a safe motivating learning environment (e.g., feel connected to and accepted by others and share this orally and on paper or using the digital tool). 
Design principle 1 Content focus. The first design principle refers specifically to the content of the CPD. In the current CPD, the content focused on providing participants with information on and skills to increase students' reading motivation (e.g., Desimone, 2009; Garet, Porter, Desimone, Birman, \& Yoon, 2001; Merchie et al., 2016). Great attention was paid to presenting and discussing a variety of motivating reading resources and materials that teachers could use in their classroom (e.g., different fictional and/or literary texts). Further, participants were taught insights from SDT (Ryan \& Deci, 2000) to provide them with information on different types of reading motivation, strategies to stimulate students' autonomous reading motivation in particular, and knowledge on approaches and resources to turn a classroom into a visibly motivating reading environment in close collaboration with students.

In Table 3, information can be found on the sessions' specific content focus per session and furthermore the implementation of the specific content focus per session is elaborated on in more detail to raise the accountability of the developed and implemented CPD program. Within the overall focus on reading motivation throughout the CPD program, each of the six sessions had an additional specific focus, namely strategies to promote reading motivation, teaching reading in a multilingual setting, differentiated instruction, assessment of reading motivation, focusing on reading in all subjects (i.e., not only during language class) and a more structural approach on reading motivation at class and school level by integrating it in a reading/language policy at school. Taking into account a growth in complexity and challenge throughout the CPD program, the additional foci are arranged in such a way that the program starts off with the most accessible focus. Therefore, strategies to promote reading motivation at class level were discussed first, since the focus on the development of a reading policy with the integration of reading motivation at school level can be considered to be more challenging. 
Table 3. Implementation per session of the CPD program on reading motivation skills

\begin{tabular}{|c|c|c|c|c|c|}
\hline Content focus per session & Goal per session & $\begin{array}{l}\text { Examples of input from } \\
\text { participants sent to the facilitator } \\
\text { before the session }\end{array}$ & $\begin{array}{l}\text { Examples of actions taken by } \\
\text { participants }(\mathrm{P}) \text { and facilitator }(\mathrm{F}) \\
\text { during the session }\end{array}$ & $\begin{array}{l}\text { Examples of plans for transfer } \\
\text { shared by participants during the } \\
\text { session }\end{array}$ & $\begin{array}{l}\text { Examples of plans put into } \\
\text { practice shared by participants } \\
\text { during the following session(s) }\end{array}$ \\
\hline $\begin{array}{l}\text { Session } 1 \\
\text { Reading motivation } \\
+ \text { Strategies to promote reading }\end{array}$ & $\begin{array}{l}\text { Goal: Participants know } \\
\text { what reading moti- } \\
\text { vation is, which types of } \\
\text { reading motivation can } \\
\text { be distinguished (i.e., } \\
\text { autonomous/controlled) } \\
\text { and which strategies } \\
\text { promote students' auto- } \\
\text { nomous reading. }\end{array}$ & $\begin{array}{l}\text {-How can I motivate my students } \\
\text { to like reading (more)? } \\
\text {-Are there any strategies that I } \\
\text { can use to stimulate my students' } \\
\text { reading motivation? } \\
\text {-How can I use my classroom } \\
\text { better in promoting my students' } \\
\text { reading motivation? }\end{array}$ & $\begin{array}{l}-F \text { asks P how they would define } \\
\text { reading motivation? And which } \\
\text { types of reading motivation they } \\
\text { think exists? } \\
-F \text { asks P how they motivate their } \\
\text { students' reading? } \\
-P \text { share strategies they use in their } \\
\text { teaching practice. F shares additi- } \\
\text { onal strategies. } \\
-P \text { share how they use their } \\
\text { classroom in view of promoting } \\
\text { their students' reading ( } P \text { were } \\
\text { asked beforehand to send pictures } \\
\text { of their classroom to the } F \text { that can } \\
\text { be shared on a screen during the } \\
\text { session); P give each other sugges- } \\
\text { tions on how to optimize their } \\
\text { classroom and resources and } F \\
\text { shares suggestions when not } \\
\text { mentioned by the } P\end{array}$ & $\begin{array}{l}-\mathrm{P} \text { will try to focus more on } \\
\text { students autonomous reading } \\
\text { motivation by responding more } \\
\text { to their need for autonomy, } \\
\text { competence, and relatedness. } \\
\text {-P will try some new strategies to } \\
\text { promote their students' reading } \\
\text { motivation. } \\
\text {-P will try to put in practice some } \\
\text { suggestions regarding the read- } \\
\text { ing environment in the class- } \\
\text { room. }\end{array}$ & $\begin{array}{l}-\mathrm{P} \text { share examples of how they } \\
\text { focused on their students' } \\
\text { autonomous reading motivation } \\
\text { (by providing choice, by helping } \\
\text { their students to choose reading } \\
\text { materials they are interested in). } \\
\text {-P share some new pictures of } \\
\text { their classrooms showing which } \\
\text { adjustments were made (making } \\
\text { reading material more visible, } \\
\text { providing a space where stu- } \\
\text { dents can give suggestions for } \\
\text { new reading materials) } \\
-P \text { share their attempts to use } \\
\text { new strategies regarding their } \\
\text { students' reading motivation } \\
\text { (book circuit, book date) }\end{array}$ \\
\hline $\begin{array}{l}\text { Session } 2 \\
\text { Reading motivation } \\
+ \text { Multilingual setting }\end{array}$ & $\begin{array}{l}\text { Goal: Participants know } \\
\text { how to promote their } \\
\text { students' reading moti- } \\
\text { vation in a multilingual } \\
\text { setting. }\end{array}$ & $\begin{array}{l}\text {-I have students who have } \\
\text { another mother tongue than the } \\
\text { language used in the classroom; } \\
\text { how can I use students' mother } \\
\text { tongue to enhance their reading } \\
\text { motivation? } \\
\text {-Where can I find reading } \\
\text { materials and resources in var- } \\
\text { ious languages? } \\
\text {-How can I promote reading in } \\
\text { the school language, while not } \\
\text { neglecting the multilingual } \\
\text { setting? }\end{array}$ & $\begin{array}{l}-F \text { asks } P \text { whether and how they } \\
\text { integrate the multilingual setting } \\
\text { their school is situated in in their } \\
\text { teaching and daily practice. } \\
\text {-P share whether and how they } \\
\text { make the multilingual context } \\
\text { visible in their classroom (regarding } \\
\text { multilingual reading materials) } \\
-F \text { asks } P \text { where they look for } \\
\text { multilingual reading materials to } \\
\text { promote their students' reading? }\end{array}$ & $\begin{array}{l}-\mathrm{P} \text { will try to be aware more of the } \\
\text { multilingual setting they are } \\
\text { working in and how this might } \\
\text { influence their students' reading } \\
\text { motivation. } \\
-\mathrm{P} \text { will try out some new reading } \\
\text { materials, proven to be moti- } \\
\text { vating in multilingual settings. } \\
-\mathrm{P} \text { will try to make reading in } \\
\text { other languages more visible in } \\
\text { their classroom. } \\
-\mathrm{P} \text { will invite parents to come and } \\
\text { read aloud during multilingual } \\
\text { reading sessions. }\end{array}$ & $\begin{array}{l}-P \text { share how the new reading } \\
\text { materials they got to know } \\
\text { worked in their classroom } \\
\text { (multilingual reading materials). } \\
-P \text { share how the multilingual } \\
\text { reading aloud sessions worked } \\
\text { for their students and how it } \\
\text { impacts their students' reading } \\
\text { motivation. } \\
-P \text { share how they made the } \\
\text { multilingual setting more visible } \\
\text { in their classroom (showing } \\
\text { various reading materials in } \\
\text { different languages next to the } \\
\text { school language) }\end{array}$ \\
\hline $\begin{array}{l}\text { Session } 3 \\
\text { Reading motivation } \\
+ \text { + Differentiated instruction }\end{array}$ & $\begin{array}{l}\text { Goal: Participants know } \\
\text { how to use differen- } \\
\text { tiated instruction to pro- } \\
\text { mote their students' } \\
\text { reading motivation. }\end{array}$ & $\begin{array}{l}\text {-I have some students who really } \\
\text { like reading and some who don't; } \\
\text { how can I keep on stimulating } \\
\text { reading in all students? } \\
\text {-Where and how can I find } \\
\text { reading materials for every } \\
\text { student in my classroom (great }\end{array}$ & $\begin{array}{l}-\mathrm{F} \text { asks } \mathrm{P} \text { whether and how they try } \\
\text { to promote each of their students' } \\
\text { reading motivation. } \\
-\mathrm{P} \text { share how they try to } \\
\text { differentiate when it comes to their } \\
\text { students' reading motivation; } F \\
\text { provides additional suggestions. } \\
-\mathrm{P} \text { share where and how they try to }\end{array}$ & $\begin{array}{l}-\mathrm{P} \text { will try to differentiate more } \\
\text { when it comes to their students' } \\
\text { reading motivation. } \\
-\mathrm{P} \text { will try to select and collect a } \\
\text { varied collection of reading } \\
\text { materials, so that their students } \\
\text { can choose according to their }\end{array}$ & $\begin{array}{l}\text {-P share how they differentiated } \\
\text { during their classes (providing } \\
\text { choices, providing a varied } \\
\text { collection of reading materials). }\end{array}$ \\
\hline
\end{tabular}


Session 4

Reading motivation

+ Assessment

Session 5

Reading motivation

+ Reading in all subjects

Session 6

Reading motivation

+ School policy regarding reading in

view of a structural approach
Goal: Participants know how their students reading motivation could be assessed and followed up.

Goal: Participants know how to focus more and better on reading in all subjects (e.g., mathematics, social studi and science) hereby and science), hereby promoting their students' reading motivation more broadly.

Goal: Participants know what a structura approach to promote their students' reading motivation could look like (at class and school level in a reading/language policy). variety of interest, level of reading comprehension).

-How can I use my classroom and available books better, so that my students can choose reading materials at their own (pace), read how and where they wish when time is made available? -How can I keep track of my students' reading motivation?

What are tools I can use to assess

my students' reading motivation?

-Is there a test for reading motivation available?

During language classes I focus a lot on reading motivation, but I orget to do so when teaching other subjects; how can I also focus on the latter?

-Are the motivar materials I can use during mathematics? Are there any strategies to promote reading during other (nses

How can I focus best on reading motivation throughout the school year?

- I certainly focus on reading motivation in the context of mationwide reading campaigns, but how can realing campaigns, but how can I also explicitly and
more purposefully focus on it during the rest of the school year?

My school has developed a language policy plan; is there also a way to integrate the focus on reading motivation in this? find reading materials that are interests, competence level, and motivating for every student; $F$ so on.

provides additional suggestions.

P share how they try to relate to

their students' preferences how

they read during reading sessions

(i.e., silent reading, reading aloud sessions).

$-F$ asks $\mathrm{P}$ whether and how they -P will try to assess their stufollow up their students' reading dents' reading motivation. motivation.

-P share whether and how they try to assess their students reading motivation; $F$ provides additional suggestions.

$-F$ asks whether and how they focus -P will try to focus more on the on their students' reading students' reading motivation in motivation when not teaching a Dutch language class. focus on their students' reading motivation when teaching for example mathematics. share motivating reading promote reading in other submaterials to be used also in other jects.

-P share strategies to promote reading also in other classes than Dutch language classes.

$-F$ asks whether and how they have a structural approach at class and school level regarding reading motivation.

$-\mathrm{P}$ share whether and how there is a reading policy available at school evel and how they transfer it to the class level.

-P share how they structurally and purposefully approach reading motivation in their classroom, next to the available nationwide reading campaigns; $F$ provides additiona suggestions.
P share how they tried to asses their students' reading motivation (using a babble box, usin a questionnaire)

$-F$ share how they tried to focus on their students' reading motivation in other classes than the Dutch language class (by starting a mathematics class by reading aloud a piece of literary text focusing on mathematics, by making various reading materials regarding other subjects visible in the classroom)

- - will ask -when not already available- their colleagues and school principal whether and when the school team could start making a plan to focus on reading (motivation) in a structural way at both school and class level.

P will try to make a plan to focus on their students' reading motivation in a more structural and purposeful way and this throughout the whole school year and not only when nationwide campaigns take place.
Not applicable since session 6 was the last session 
Design principle 2 Active learning. The second design principle focuses on participants' continuing inquiry of practice, co-creation of and reflection on professional and academic knowledge and skills to increase students' reading motivation (e.g., Desimone, 2009; McArdle \& Coutts, 2010; Merchie et al., 2016; Postholm, 2012). In active learning sessions participants' classroom practices to foster students' reading motivation were shared, observed, and discussed. Moreover, lessons and materials to promote students' reading motivation were designed and developed in collaboration between the participants and the facilitator. In addition, continuing reflection on real classroom practice was included from the second CPD session onwards, by reflecting on teachers' actual classroom experiences with the implementation of what was developed in the previous CPD session and by discussing their students' reactions to it (i.e., possibly leading to adjusted versions of earlier developed material and/or lessons).

Design principle 3 Coherence. The third design principle focuses on the alignment of the CPD program with participants' goals, beliefs and with current educational reforms and policies to increase students' reading motivation (e.g., Desimone, 2009; Merchie et al., 2016; Penuel, Fishman, Yamaguchi, \& Gallagher, 2007). This design principle was operationalized by paying great attention to getting acquainted with and discussing participating teachers' daily teaching practice. As in Flanders no official attainment targets are present when it comes to students' reading motivation, the facilitator focused on aligning the content and approach of the sessions with teachers' beliefs and the personal goals teachers wanted to achieve regarding their students' reading motivation. In respect to the latter, Table 3 contains examples of participating teachers' input and what was elaborated on during the sessions.

Design principle 4 Duration. The fourth design principle ensures that participants took part in an extended and intensive CPD program, of sufficient duration with activities that are spread out in time and include at least 20 hours of contact time (e.g., Desimone, 2009; Merchie et al., 2016; Yoon et al., 2007) in order to raise the possible impact of the program. Therefore, a year-long program was developed, where both the facilitator and participating teachers met six times in person throughout the school year during sessions of approximately four hours each. Participating teachers were asked to prepare well in advance for each session. They were asked to prepare questions and examples of teaching practices (with photos or video-material), and to bring along relevant teaching materials to show and share with the other participating teachers and the facilitator. In between the six face-toface sessions, online follow-ups were also part of the program. To enable these follow-ups, an online communication tool was chosen by the participants during the first session and was actively used throughout the CPD program as a platform to share teaching practices, discussing these, giving feedback, or asking questions regarding daily teaching practice in view of continuingly stimulating students' reading motivation. The planned number of six sessions was deliberately opted for (i.e., apart from the holiday periods the sessions took place approximately every 6 to 8 weeks) taking into account the evidence-based guideline from the literature that 
at least 20 hours of contact time throughout a longer period is required (e.g., Desimone, 2009; Merchie et al., 2016; Yoon et al., 2007) and considering the fact that the participating teachers needed time to put in practice what was learned in the (previous) session(s) and to prepare the following session(s).

Design principle 5 Collective participation. The fifth design principle focuses on the participants collaborating on each other's teaching practices to increase students' reading motivation (e.g., Desimone, 2009; Hochberg \& Desimone, 2010; Merchie et al., 2016). Based on this design principle, the facilitator and participating teachers shared and elaborated on content-focused teaching practices, interacted about participants' teaching practices (e.g., through discussions and providing feedback) and collaborated and co-created actively, for example by designing lessons, selecting motivating reading materials and developing step-by-step plans to integrate them in their classroom practice in collaboration with their students.

Design principle 6 Autonomy support. The sixth design principle focuses on the participants' need for autonomy (i.e., the experience of a sense of volition or psychological freedom) (e.g., Ryan \& Deci, 2000; De Naeghel et al, 2016). Based on this design principle the facilitator provided the participating teachers with choices to fit their interests and considering thoroughly the participants' perspective. On the other hand, the facilitator stimulated the teachers to examine and put into practice how they themselves could focus more on students' autonomy support in their daily reading practice by applying the same motivating teacher behavior. Importantly and in line with providing autonomy to the participants, only the first face-to-face session had a fixed date and location. The date and location of all other sessions were decided upon by the participating teachers together, opening the possibility for meeting at different motivating locations (e.g., classrooms, libraries) and bearing in mind all participants' agendas. As to the location of the sessions, the first session took place at the campus of a university college. As requested by the participating teachers, the next sessions took place alternately at their own schools (i.e., in the classrooms), except for one session that took place in an organization with a variety of materials and resources available regarding the multilingual setting the participating teachers were working in.

Design principle 7 Competence support. The seventh design principle focused on the participants' need for competence (i.e., the experience of being confident and effective in action) (e.g., Ryan \& Deci, 2000; De Naeghel et al, 2016). The facilitator focused on stimulating the participating teachers to communicate their expectations regarding the CPD, providing them optimal challenges, offering them help and support, and providing them with constructive feedback. On the other hand, the facilitator stimulated the teachers to examine and put in practice how they could focus on providing structure to students in their daily reading practice by applying the same motivating teacher behavior.

Design principle 8 Relatedness support. The eighth design principle focused on the participants' need for relatedness (i.e., the experience of feeling connected to and accepted by others) (e.g., Ryan \& Deci, 2000; De Naeghel et al, 2016). On the one hand, the facilitator created a safe and motivating learning environment for the 
teachers, where the participating teachers were welcomed to be strongly involved and work in collaboration. On the other hand, the facilitator stimulated the participants to examine and put into practice how they could focus on providing relatedness support to their students in their daily reading practice by applying the same motivating teacher behavior.

\section{Implementation check of the design principles}

At the end of a CPD session, the implementation check questionnaire was completed by the participants, the facilitator, and an external observer. Based on the scores per session, it can be stated that both the participating teachers and the external observer perceived the CPD program's underlying design principles as intended by the researchers (see Table 4). Overall, the participants' mean scores were high in all sessions and the standard deviations were small, indicating that they perceived the underlying design principles in a similar way and in line with the perception of the external observer. Across four sessions, she mainly rated the statements as "true" (29\%) or "completely true" (67\%). The facilitator's ratings were either "sometimes true/sometimes not true" (21\%) or "true" (79\%). 
Table 4. Quality of implementation of the CPD program's underlying design principles

\begin{tabular}{|c|c|c|c|c|c|c|c|c|c|c|c|c|c|c|c|c|c|c|}
\hline & \multicolumn{18}{|c|}{$M$ and $S D$} \\
\hline & Session 1 & & & Session 2 & & & Session 3 & & & Session 4 & & & Session 5 & & & Session 6 & & \\
\hline & $\mathrm{Pa}_{\mathrm{a}}$ & $E_{b}$ & $\mathrm{~F}_{\mathrm{c}}$ & $\mathrm{Pa}$ & $E_{b}$ & $F_{c}$ & $\mathrm{~Pa}$ & $E_{b}$ & $\mathrm{~F}_{\mathrm{c}}$ & $\mathrm{Pa}$ & $E_{b}$ & $\mathrm{~F}_{\mathrm{c}}$ & $\mathrm{Pa}$ & $E_{b}$ & $\mathrm{~F}_{\mathrm{c}}$ & $\mathrm{Pa}$ & $E_{b}$ & $\mathrm{~F}_{\mathrm{c}}$ \\
\hline Content focus & $\begin{array}{l}M=4.13 \\
S D=0.35\end{array}$ & 5.0 & 4.0 & $\begin{array}{l}M=4.17 \\
S D=0.75\end{array}$ & 4.0 & 3.0 & $\begin{array}{l}M=4.17 \\
S D=0.41\end{array}$ & 5.0 & 4.0 & $\begin{array}{l}M=4.40 \\
S D=0.55\end{array}$ & 5.0 & 4.0 & $\begin{array}{l}M=4.50 \\
S D=0.55\end{array}$ & & 4.0 & $\begin{array}{l}M=4.40 \\
S D=0.55\end{array}$ & & 4.0 \\
\hline Active learning & $\begin{array}{l}M=3.88 \\
S D=0.64\end{array}$ & 4.0 & 3.0 & $\begin{array}{l}M=4.17 \\
S D=0.75\end{array}$ & 4.0 & 3.0 & $\begin{array}{l}M=4.17 \\
S D=0.41\end{array}$ & 4.0 & 3.0 & $\begin{array}{l}M=4.60 \\
S D=0.55\end{array}$ & 3.0 & 3.0 & $\begin{array}{l}M=4.83 \\
S D=0.41\end{array}$ & & 3.0 & $\begin{array}{l}M=4.60 \\
S D=0.89\end{array}$ & & 3.0 \\
\hline Coherence & $\begin{array}{l}M=4.00 \\
S D=0.76\end{array}$ & & 4.0 & $\begin{array}{l}M=4.17 \\
S D=0.75\end{array}$ & & 4.0 & $\begin{array}{l}M=4.33 \\
S D=0.82\end{array}$ & & 4.0 & $\begin{array}{l}M=4.40 \\
S D=0.55\end{array}$ & & 4.0 & $\begin{array}{l}M=4.33 \\
S D=0.52\end{array}$ & & 4.0 & $\begin{array}{l}M=4.40 \\
S D=0.55\end{array}$ & & 4.0 \\
\hline $\begin{array}{l}\text { Collective } \\
\text { participation }\end{array}$ & $\begin{array}{l}M=4.75 \\
S D=0.46\end{array}$ & 5.0 & 4.0 & $\begin{array}{l}M=4.33 \\
S D=0.52\end{array}$ & 5.0 & 3.0 & $\begin{array}{l}M=4.63 \\
S D=0.82\end{array}$ & 5.0 & 4.0 & $\begin{array}{l}M=4.80 \\
S D=0.45\end{array}$ & 4.0 & 3.0 & $\begin{array}{l}M=4.83 \\
S D=0.41\end{array}$ & & 4.0 & $\begin{array}{l}M=4.60 \\
S D=0.55\end{array}$ & & 4.0 \\
\hline $\begin{array}{l}\text { Autonomy } \\
\text { support }\end{array}$ & $\begin{array}{l}M=4.88 \\
S D=0.35\end{array}$ & 4.0 & 4.0 & $\begin{array}{l}M=4.83 \\
S D=0.41\end{array}$ & 5.0 & 4.0 & $\begin{array}{l}M=4.67 \\
S D=0.52\end{array}$ & 4.0 & 4.0 & $\begin{array}{l}M=5.00 \\
S D=0.00\end{array}$ & 5.0 & 4.0 & $\begin{array}{l}M=4.67 \\
S D=0.52\end{array}$ & & 4.0 & $\begin{array}{l}M=4.40 \\
S D=0.55\end{array}$ & & 4.0 \\
\hline $\begin{array}{l}\text { Competence } \\
\text { support }\end{array}$ & $\begin{array}{l}M=4.63 \\
S D=0.52\end{array}$ & 5.0 & 4.0 & $\begin{array}{l}M=4.33 \\
S D=0.52\end{array}$ & 5.0 & 4.0 & $\begin{array}{l}M=4.83 \\
S D=0.41\end{array}$ & 5.0 & 4.0 & $\begin{array}{l}M=4.80 \\
S D=0.45\end{array}$ & 5.0 & 4.0 & $\begin{array}{l}M=4.67 \\
S D=0.52\end{array}$ & & 4.0 & $\begin{array}{l}M=4.80 \\
S D=0.45\end{array}$ & & 4.0 \\
\hline $\begin{array}{l}\text { Relatedness } \\
\text { support }\end{array}$ & $\begin{array}{l}M=4.38 \\
S D=0.12\end{array}$ & 5.0 & 4.0 & $\begin{array}{l}M=4.33 \\
S D=1.03\end{array}$ & 5.0 & 4.0 & $\begin{array}{l}M=5.00 \\
S D=0.00\end{array}$ & 5.0 & 4.0 & $\begin{array}{l}M=5.00 \\
S D=0.00\end{array}$ & 5.0 & 4.0 & $\begin{array}{l}M=4.83 \\
S D=0.41\end{array}$ & & 4.0 & $\begin{array}{l}M=4.60 \\
S D=0.55\end{array}$ & & 4.0 \\
\hline
\end{tabular}

Note. $P_{a}$ refers to the participants $(N=8)$. Eb refers to the external observer $(N=1)$ and $F_{c}$ refers to the facilitator $(N=1)$; scale ranging from 1 to $5 ; 1=$ not true at all, $2=$ not true, $3=$ sometimes true/sometimes not true, $4=$ true and $5=$ completely true. 


\section{DISCUSSION}

The literature denotes the lack of clear and detailed descriptions of design principles underlying CPD programs. Therefore, the present study described the design principles, their operationalization and implementation in a CPD program supporting primary school teachers in fostering their students' reading motivation. In addition, an implementation check was executed for the first iteration of this intervention, to examine whether the CPD participants perceived the design principles as intended. Below, the added value and limitations of this approach are discussed and suggestions for future research are formulated.

Based on the literature study both Desimone's (2009) framework for effective professional development integrating a theory of change and instruction and SDT as an important motivational theory appeared to be essential in developing a wellgrounded CPD program. Consequently, their key design principles were selected and analyzed. However, it is not sufficient to only list design principles underlying a program (e.g., Rijlaarsdam et al., 2018). As has been done in the present study, these principles also need to be operationalized in close relation to the program's overall focus, by for example mentioning the rationale behind each of the selected design principles and developing facilitator's instructional and participants' learning activities simultaneously and in alignment with the principles. This kind of reporting approach can enhance future implementation or the dissemination and evaluation of the CPD, as these operationalized design principles could be used as guidelines supporting researchers or educational practitioners in gaining more insight into these principles and possibly implement them in professional development trajectories.

In line with the emerging literature on treatment fidelity of educational interventions (e.g., O'Donnell, 2008) and in view of developing further iterations of the CPD, an implementation check of the current program's underlying design principles was executed to provide insight into how the design principles were perceived by the CPD participants. In the present study a multi-actor approach was used, hence next to the teacher participants also an external observer and the facilitator rated the underlying design principles. It was noted that all involved parties positively experienced the inclusion of the design principles in the CPD program as intended by the researchers. The facilitator's scores were somewhat more critical compared to the other raters, but this could be attributed to her specific and possibly more critical role in the CPD program, where she needed to continuingly (i.e., from one session to the other) monitor the rigorous attendance to the design principles and ways to best put them into practice. However, the facilitator's scores were only related to one person, which compared to the group mean scores should also be interpreted with caution. The finding that the external observer positively perceived the inclusion of the design principles in the CPD program can be considered beneficial in view of the implementation check, because of the independent role she had. 
Although a short questionnaire with a single item per scale was opted for to raise the practicability and the probability that all participants could fill it out easily at the end of every session, as a next step, it might be worthwhile to (1) further improve the questionnaire by using multiple items per scale and examine their reliability and (2) also integrate qualitative measures to check the implementation quality of the CPD program's underlying design principles (e.g., using a group discussion, individual interviews or observation). Such a mixed-method approach, combining both quantitative and qualitative results might provide deeper insights into how participants experience each of these design principles (e.g., Creswell, \& Clark, 2010; Desimone, 2009; Thurlings \& den Brok, 2017).

In future papers attention could also be paid to the social validity of the CPD. More particularly, studying teachers' perception of the goals, procedures and outcomes of the CPD will provide insight in their satisfaction, acceptability, and applicability of the practices developed in and reflected upon in the CPD (e.g., for reviews, see Gresham \& Lopez, 1996; Schwartz \& Bear, 1991). This might also help disentangling whether teachers will continue using the reading motivational approaches after completion of the CPD. Moreover, also the effectiveness of the program could be reported on in further papers. In this respect, both the impact on teachers (e.g., on their knowledge, self-efficacy beliefs, reading promotive behavior in the class) and the subsequent impact on their students' reading outcomes and reading motivation should be addressed. Regarding the latter, it will be worthwhile to consider a follow-up to the CPD presented in the present paper, for example using an additional one-on-one approach aiming at further coaching on the job (e.g., Kretlow \& Bartholomew, 2010) or adjusting the frequency of contact, in view of encouraging sustained implementation of the new teaching practices.

To conclude, it can be stated that it is important for researchers to identify the design principles underlying their CPD programs. However, it is not only important to just identify these principles, but also to operationalize each principle into specific activities to be of use for future implementations, replications, and evaluations (e.g., King, 2014). That is, it is critical to share how principles can be put into practice by the facilitator of a program, in combination with the learning activities of the participants. In addition, it is advisable to bear in mind the overall value of executing an implementation check, as this might shed more light on how and whether the program's design principles are being experienced as such by the participants.

\section{REFERENCES}

Aelterman, N., Vansteenkiste, M., Van Keer, H., De Meyer, J., Van den Berghe, L., \& Haerens, L. (2013). Development and evaluation of a training on need-supportive teaching in physical education: Qualitative and quantitative findings. Teaching and Teacher Education, 29(1), 64-75. https://doi.org/10.1016/j.tate.2012.09.001

Afflerbach, P., Cho, B. Y., Kim, J. Y., Crassas, M. E., \& Doyle, B. (2013). Reading: What else matters besides strategies and skills? Reading Teacher, 66(6), 440-448. https://doi.org/10.1002/TRTR.1146

Alexander, P. A. (2012). Reading into the future: Competence for the 21st century. Educational Psychologist, 47(4), 259-280. doi:10.1080/00461520.2012.722511 
Applegate, A. J., Dekonty Applegate, M., Mercantini, M. A., McGeehan, C. M., Cobb, J. B., Deboy, J. R., Modla, V.B, \& Lewinski, K. E. (2014). The Peter Effect revisited: Reading habits and attitudes of college students. Literacy Research and Instruction, 53, 188-204. https://doi.org/10.1080/19388071.2014.898719

Avalos, B. (2011). Teacher professional development in Teaching and Teacher Education over ten years. Teaching and Teacher Education, 27(1), 10-20. https://doi.org/10.1016/j.tate.2010.08.007

Bandura, A. (1986). Social foundations of thought and action: A social cognitive theory. Upper Saddle River, NJ: Prentice Hall

Borko, H. (2004). Professional development and teacher learning: Mapping the terrain. Educational Researcher, 33(8), 3-15. https://doi.org/10.3102/0013189X033008003

Boston, M. D. (2013). Connecting changes in secondary mathematics teachers' knowledge to their experiences in a professional development workshop. Journal of Mathematics Teacher Education, 16(1), 7-31. doi:10.1007/s10857- 012-9211-6.

Coe, R., Aloisi, C., Higgins, S., \& Major, L. E. (2014). What makes great teaching? Review of the underpinning research. Project Report. Sutton Trust, London, 1-57. Thousand Oaks, CA: Sage Publications, Inc.

Conradi, K., Jang, B. G., \& McKenna, M. C. (2013). Motivation Terminology in Reading Research: A Conceptual Review. Educational Psychology Review, 26(1), 127-164. https://doi.org/10.1007/s10648-013-9245-z

Creswell, J. W. \& Clark, L. P. (2010). Designing and conducting mixed methods research. Thousand Oaks, CA: Sage Publications, Inc.

De Naeghel, J., Van Keer, H., Vansteenkiste, M., \& Rosseel, Y. (2012). The relation between elementary students' recreational and academic reading motivation, reading frequency, engagement, and comprehension: A self-determination theory perspective. Journal of Educational Psychology, 104(4), 1006-1021. https://doi.org/10.1037/a0027800

De Naeghel, J., Van Keer, H., Vansteenkiste, M., Haerens, L., \& Aelterman, N. (2016). Promoting elementary school students' autonomous reading motivation: effects of a teacher professional development workshop. The Journal of Educational Research, 109(3), 232-252. https://doi.org/10.1080/00220671.2014.942032

De Naeghel, J., Valcke, M., De Meyer, I., Warlop, N., van Braak, J., \& Van Keer, H. (2014). The role of teacher behavior in adolescents' intrinsic reading motivation. Reading and Writing, 27(9), 1547-1565. https://doi.org/10.1007/s11145-014-9506-3

Naeghel, J. De, Keer, H. Van, \& Vanderlinde, R. (2014). Strategies for promoting autonomous reading motivation: A multiple case study research in primary education, Frontline Learning Research, 2(1), 83-101. https://doi.org/10.14786/flr.v2i1.84

De Smedt, F., Graham, S., \& Van Keer, H. (2018). The bright and dark side of writing motivation: Effects of explicit instruction and peer assistance. Journal of Educational Research. https://doi.org/10.1080/00220671.2018.1461598

Desimone, L. M. (2009). Improving impact studies of teachers' professional development: toward better conceptualizations and measures. Educational Researcher, 38(3), 181-199. https://doi.org/10.3102/0013189X08331140

Dumas, J., Lynch, A., Laughlin, J., Smith, E., \& Prinz, R. (2001). Promoting intervention fidelity: Conceptual issues, methods and preliminary results form the Early Alliance prevention trial. American Journal of Preventive Medicine, 20(1), 38-47. doi:10.1016/S0749-3797(00)00272-5

Garet, M. S., Porter, A. C., Desimone, L., Birman, B. F., \& Yoon, K. S. (2001). What makes professional development effective? Results from a national sample of teachers. American Educational Research Journal, 38(4), 915-945. https://doi.org/10.3102/00028312038004915

Gresham, F. M., \& Lopez, M. F. (1996). Social validation: A unifying concept for school-based consultation research and practice. School Psychology Quarterly, 11(3), 204-227. https://doi.org/10.1037/h0088930

Guthrie, J. T., \& Wigfield, A. (2000). Engagement and motivation in reading. In Handbook of reading research, (403-422). https://doi.org/10.1023/A:1016627907001

Guthrie, J. T., \& Klauda, S. L. (2014). Effects of classroom practices on reading comprehension, engagement, and motivations for adolescents. Reading Research Quarterly, 49(4), 387-416. https://doi.org/10.1002/rrq.81 
Guskey, T. R. (2000). Evaluating professional development. Thousand Oaks, CA: Corwin press.

Guskey, T. R. (2014). Evaluating Professional Learning. In S. Billett (Ed.) International Handbook of Research in Professional and Practice-based Learning, (1215-1235). New York, NY: Springer International.

Hattie, J. (2009). Visible learning. A synthesis of over 800 meta-analyses relating to achievement. London, UK: Routledge.

Hochberg, E. D., \& Desimone, L. M. (2010). Professional development in the accountability context: Building capacity to achieve standards. Educational Psychologist, 45(2), 89-106. https://doi.org/10.1080/00461521003703052

Hornstra, L., van der Veen, I., Peetsma, T., \& Volman, M. (2013). Developments in motivation and achievement during primary school: A longitudinal study on group-specific differences. Learning and Individual Differences, 23, 195-204. https://doi.org/10.1016/j.lindif.2012.09.004

Jang, B. G., Conradi, K., McKenna, M. C., \& Jones, J. S. (2015). Motivation: Approaching an elusive concept through the factors that shape it. Reading Teacher, 69(2), 239-247. https://doi.org/10.1002/trtr.1365

Kang, H. S., Cha, J. \& Ha., B.-W. (2013). What should we consider in teachers' professional development impact studies? Based on the conceptual framework of Desimone. Creative Education, 4, 11-18. doi:10.4236/ce.2013.44A003.

Kelchtermans, G. (2004). CPD for professional renewal: moving beyond knowledge for practice. In C. Day, $\& \mathrm{~J}$. Sachs (Eds.), International handbook on the continuing professional development of teachers (217-237). Maidenhead: Open University Press.

Kennedy, A. (2014). Understanding continuing professional development: the need for theory to impact on policy and practice. Professional Development in Education, 40(5), 688-697. https://doi.org/10.1080/19415257.2014.955122

Kennedy, M. M. (2016). How does professional development improve teaching? Review of Educational Research, 1-36. https://doi.org/10.3102/0034654315626800

King, F. (2014). Evaluating the impact of teacher professional development: an evidence-based framework. Professional Development in Education, 40(1), 89-111. https://doi.org/10.1080/19415257.2013.823099

Klauda, S. L., \& Guthrie, J. T. (2015). Comparing relations of motivation, engagement, and achievement among struggling and advanced adolescent readers. Reading and Writing, 28(2), 239-269. https://doi.org/10.1007/s11145-014-9523-2

Kretlow, A. G., \& Bartholomew, C. C. (2010). Using coaching to improve the fidelity of evidence-based practices: A review of studies. Teacher Education and Special Education: The Journal of the Teacher Education Division of the Council for Exceptional Children, 33(4), 279-299. https://doi.org/10.1177/0888406410371643

Labone, E., \& Long, J. (2016). Features of effective professional learning: a case study of the implementation of a system-based professional learning model. Professional Development in Education, 42(1), 54-77. https://doi.org/10.1080/19415257.2014.948689

Lazowski, R. A, \& Hulleman, C. S. (2015). Motivation interventions in education: A meta-analytic review. Review of Educational Research, 39, 1-39. https://doi.org/10.3102/0034654315617832

Leu, J. L., Kinzer, C. K., Coiro, J., Castek, J., \& Henry, L. A. (2013). New Literacies: A dual-level theory of the changing nature of literacy, instruction, and assessment. In D. E. Alvermann, J. U. Unrau, \& R. B. Ruddell (Eds.), Theoretical models and processes of reading (6th ed., 1150-1181). Newark, DE: International Reading Association.

McArdle, K., \& Coutts, N. (2010). Taking teachers' continuous professional development (CPD) beyond reflection: Adding shared sense-making and collaborative engagement for professional renewal. Studies in Continuing Education, 32(3), 201-215. https://doi.org/10.1080/0158037X.2010.517994

McKenna, M. C., Conradi, K., Lawrence, C., Jang, B. G., \& Meyer, J. P. (2012). Reading attitudes of middle school students: Results of a U.S. survey. Reading Research Quarterly, 47(3), 283-306. https://doi.org/10.1002/RRQ.021

McKool, S. S., \& Gespass, S. (2009). Does Johnny's reading teacher love to read? How teachers' personal reading habits affect instructional practices. Literacy Research and Instruction, 48(3), 264-276. https://doi.org/10.1080/19388070802443700

Merchie, E., Tuytens, M., Devos, G., \& Vanderlinde, R. (2016). Evaluating teachers' professional development initiatives: towards an extended evaluative framework. Research Papers in Education, 
1522(March), 1-26. https://doi.org/10.1080/02671522.2016.1271003

Merga, M. K. (2015). “" She knows what I like "': best-practice statements for encouraging recreational book reading in adolescents. Australian Journal of Education, 59(1), 35-50. https//doi.org/10.1177/0004944114565115

Morrison, T. G., Jacobs, J. S., \& Swinyard, W. R. (1998). Do teachers who read personally use recommended literacy practices in their classrooms? Reading Research and Instruction, 38(2), 81100. https://doi.org/10.1080/19388079909558280

Mullis, I. V. S., Martin, M. O., Foy, P., \& Drucker, K. T. (2012). PIRLS 2011 international results in reading. Chestnut Hill: TIMSS \& PIRLS International Study Center, Boston College.

Mullis, I. V. S., Martin, M. O., Foy, P., \& Hooper, M. (2017). PIRLS 2016 international results in reading. Chestnut Hill: TIMSS \& PIRLS International Study Center, Boston College.

Nathanson, S., Pruslow, J., \& Levitt, R. (2008). The reading habits and literacy attitudes of inservice and prospective teachers: Results of a questionnaire survey. Journal of Teacher Education, 59(4), 313321. https://doi.org/10.1177/0022487108321685

O’Donnell, C. L. (2008). Defining, conceptualizing, and measuring fidelity of implementation and its relationship to outcomes in K-12 curriculum intervention research. Review of Educational Research, 78(1), 33-84. https://doi.org/10.3102/0034654307313793

Opfer, V. D., \& Pedder, D. (2011). Conceptualizing teacher professional learning. Review of Educational Research, 81(3), 376-407. https://doi.org/10.3102/0034654311413609

Organisation for Economic Co-operation and Development (OECD) (2010). PISA 2009 Results: Executive Summary. Paris: OECD Publishing.

Organisation for Economic Co-operation and Development (OECD) (2014).TALIS 2013 Results: An International Perspective on Teaching and Learning, Paris: OECD Publishing.

Penuel, W. R., Fishman, B. J., Yamaguchi, R., \& Gallagher, L. P. (2007). What makes professional development effective? Strategies that foster curriculum implementation. American Educational Research Journal, 44, 921-958. doi:10.3102/0002831207308221

Postholm, M. B. (2012). Teachers' professional development: A theoretical review. Educational Research, 54(4), 405-429. https://doi.org/10.1080/00131881.2012.734725

Rijlaarsdam, G., Janssen, T., Rietdijk, S., \& van Weijen, D. (2018). Reporting design principles for effective instruction of writing: Interventions as constructs. In R. Fidalgo, K. Harris, \& M. Braaksma (Eds.), Design principles in writing instruction. Leiden, The Netherlands: Brill. https://doi.org/10.1163/9789004270480_013

Ryan, R. M., \& Deci, E. L. (2000). Self-determination theory and the facilitation of intrinsic motivation, social development, and well-being. American Psychologist, 55, 68-78.

Sainsbury, M., \& Schagen, I. (2004). Attitudes to reading at ages nine and eleven. Journal of Research in Reading, 27(4), 373-386. https://doi.org/10.1111/j.1467-9817.2004.00240.x

Santagata, R., \& Bray, W. (2015). Professional development processes that promote teacher change: the case of a video-based program focused on leveraging students' mathematical errors. Professional Development in Education, 1-22. https://doi.org/10.1080/19415257.2015.1082076

Schiefele, U., Schaffner, E., Möller, J., \& Wigfield, A. (2012). Dimensions of reading motivation and their relation to reading behavior and competence. Reading Research Quarterly. 47(4), 427-463. doi:10.1002/RRQ.030

Schwartz, I. S., \& Baer, D. M. (1991). Social validity assessments: is current practice state of the art? Journal of Applied Behavior Analysis, 24(2), 189-204. https://doi.org/10.1901/jaba.1991.24-189

Smith, S. W., Daunic, A. P., \& Taylor, G. G. (2007). Treatment fidelity in applied educational research: Expanding the adoption and application of measures to ensure evidence-based practice. Education and Treatment of Children, 30(4), 121-134. https://doi.org /10.1353/etc.2007.0033

Sullivan, A., \& Brown, M. (2013). Social inequalities in cognitive scores at age 16: The role of reading. London, Centre for longitudinal studies.

Swanson, E., Wanzek, J., Haring, C., Ciullo, S., \& McCulley, L. (2013). Intervention fidelity in special and general education research journals. Journal of Special Education, 47(1), 3-13. https://doi.org/10.1177/0022466911419516

Swennen, A., Lunenberg, M., \& Korthagen, F. (2008). Preach what you teach! Teacher educators and congruent teaching. Teachers and Teaching, 14(5), 531-542. https://doi.org/10.1080/13540600802571387 
Thurlings, M., \& den Brok, P. (2017). Learning outcomes of teacher professional development activities: a meta-study. Educational Review, 69(5), 554-576. https://doi.org/10.1080/00131911.2017.1281226

Timperley, H., Wilson, A., Barrar, H., \& Fung, I. (2007). Teacher professional learning and development. Best evidence synthesis iteration. Wellington, New Zealand: Ministry of Education. https://doi.org/10.1111/j.1744-7984.2007.00116.x

Vansteelandt, I., Mol, S.E., Caelen, D., Landuyt, I. \& Mommaerts, M. (2017). Attitude profiles explain differences in pre-service teachers' reading behavior and competence beliefs. Learning and Individual Differences, 54, 109 -115. https://doi.org/10.1016/j.lindif.2017.01.016

Van Steensel, R., van der Sande, L., Bramer, W., \& Arends, L. (2016). Effecten van leesmotivatieinterventies. Uitkomsten van een meta-analyse. Reviewstudie in opdracht van het Nationaal Regieorgaan Onderwijsonderzoek

Van Veen, K., Zwart, R. \& Meirink, J. (2012) “What makes teacher professional development effective? A literature review." In M. Kooy and K. van Veen (Eds.). Teacher Learning That Matters: International Perspectives, 3-21. New York: Routledge.

Wei, R. C., Darling-Hammond, L., Andree, A., Richardson, N., \& Orphanos, S. (2009). Teacher PD Tech Report: A status report on teacher development in the U.S. and abroad. Dallas, TX. National Staff Development Council. https://doi.org/10.1006/jfbi.2002.2063

Wigfield, A., \& Eccles, J. S. (2000). Expectancy-value theory of achievement motivation. Contemporary Educational Psychology, 25, 68-81. doi:10.1006/ceps.1999.1015

Wigfield, A., Gladstone, J. R., \& Turci, L. (2016). Beyond cognition: Reading motivation and reading comprehension. Child Development Perspectives, 10(3), 190-195. https://doi.org/10.1111/cdep.12184

Yoon, K. S., Duncan, T., Lee, S. W.-Y., Scarloss, B., \& Shapley, K. L. (2007). Reviewing the evidence on how teacher professional development affects student achievement. Issues and Answers Report, (REL 2007-No. 33), 62. Washington, DC: U.S. Department of Education, Institute of Education Sciences, National Center for Education Evaluation and Regional Assistance, Regional Educational Laboratory Southwest. https://doi.org/10.3102/0002831208328088

\section{APPENDIX}

\section{Information on the CPD-program on reading motivation}

First of all: You are doing a great job! As a newly qualified teacher you need to be praised, because every day you are there for your students, wanting them to learn a lot!

\section{Why then still this CPD-program?}

We want to keep on being there for you! Especially as a newly qualified teacher you have a lot on your mind. Therefore, it is really important for you to keep on professionalizing together with others, by developing and evaluating new reading materials and instructional strategies for teaching reading, sharing suggestions on how to continue fostering your students' reading motivation, and so on. 


\section{Why the specific focus on reading motivation?}

Research has repeatedly shown that reading is key for participating in our education and society. We are constantly reading, going from reading text messages to the reading of books, manuals, and so on. Students are doing it constantly at school, not only during language courses. Research has also revealed a close relationship between students' reading motivation, reading behavior and reading performance on the one hand and the important role teachers have in this on the other hand.

\section{Why an additional focus for each session?}

Each session focuses on reading motivation, but has an additional focus as well, respectively strategies to promote reading motivation, reading motivation and the multilingual setting, differentiated instruction, assessment of reading motivation, reading motivation in all subjects, and school policy regarding reading motivation in view of a structural approach. We opt for these extra foci because they align well with your daily teaching practice and they will make you reflect broadly and purposively on your own daily practice regarding your students' reading motivation.

\section{What is expected of you?}

Timing

- We meet each other six times throughout the school year.

- The date of the first session is fixed (see planning); the other sessions will be scheduled during the sessions.

Location

- The first time we meet at the campus of the university college. A badge will be ready for you.

- The location of the next sessions will be decided on during the sessions.

Focus sessions

- You bring your daily teaching practice to the sessions (linked to reading motivation and the additional focus of each session). More specifically, you share the questions you have, good practices you want to share, ideas on lessons you want to work on jointly, materials you want to share, video or photo material you made during your lessons, and so on.

- Together we address all the input given and work actively and collaboratively on it. From the second session onwards we provide time to share and discuss experiences based on what was learnt in the previous session.

- We mainly work hands-on, which leads to practical materials, lessons and feedback that you can work with in your daily teaching practice. It is our goal that you do not leave a session empty handed.

- During the first session we decide on which tool we will use to collect and share all the materials made. 
- We make each session also as pleasant as possible; having something to eat and drink is part of that.

Assignments before each session

- At least three days before the session you send your input to your facilitator, who will use this to prepare the session, in order to be able to work as efficiently and purposefully as possible.

Contact in between each session

- During the first session we decide on which online tool we will use to keep in touch in between the sessions.

- Using this online tool, we will also be able so share questions, materials, and so on.

Feedback on each session

- At the end of each session you will be asked to give feedback; therefore, you will be asked to fill out a short questionnaire.

- The purpose of the sessions it that we jointly go for a productive and pleasant professional development journey and that we work actively and collaboratively on the enhancement of your knowledge and skills on promoting your students' reading (motivation) and in that way strengthening your students' reading (motivation). 